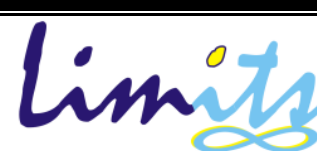

Limits: Journal of Mathematics and Its Applications

E-ISSN: 2579-8936

P-ISSN: 1829-605X

Vol. 17, No. 2, Desember 2020, 123-137

DOI: http://dx.doi.org/10.12962/limits.v17i2.6650

\title{
Konstruksi Brace Dua Sisi Dengan Menggunakan Ring Jacobson
}

\author{
Puguh Wahyu Prasetyo ${ }^{1^{*}}$, Catur Yustika Melati ${ }^{2}$ \\ ${ }^{1,2}$ Universitas Ahmad Dahlan; Kampus 4 UAD, Jalan Lingkar Selatan, Tamanan, Bantul DIY \\ Program Studi Pendidikan Matematika Universitas Ahmad Dahlan, Indonesia \\ puguh.prasetyo@pmat.uad.ac.id
}

Diajukan:26 Februari 2020, Diperbaiki: 6 Desember 2020, Diterima:12 Desember 2020

\begin{abstract}
Abstrak
Dalam perkembangan ilmu pengetahuan alam, matematika dan fisika merupakan ilmu-ilmu sains dasar yang merupakan fundamental bagi cabang ilmu yang lain. Dalam perkembangan ilmu Fisika seringkali juga memotivasi adanya temuan-temuan baru dalam ilmu matematika khususnya aljabar. Di lain pihak, banyak permasalahan dalam fisika teoritis dapat diselesaikan melalui pendekatan aljabar. Dalam kesempatan ini, salah satu bukti hubungan antara fisika dan matematika (khususnya aljabar) diberikan. Pada tahun 1967 suatu persamaan fundamental dalam Ilmu fisika ditemukan oleh penerima hadiah Nobel C. N. Yang. Dalam kurun waktu yang sama, persamaan ini juga diklaim ditemukan oleh R. J. Baxter. Oleh sebab itu, persamaan fundamental ini disebut dengan persamaan Yang-Baxter. Faktanya, persamaan Yang-Baxter ini mempunyai dampak besar dalam perkembangan ilmu pengetahuan, salah satunya adalah dalam Teori Knot. Akan tetapi solusi analitik dari persamaan ini belum ditemukan hingga saat ini. Hal ini memotivasi para peneliti untuk menemukan solusinya baik secara kualitatif maupun kuantitatif. Beberapa solusi pendekatan kualitatif telah ditemukan dengan menggunakan pendakatan struktur aljabar yang disebut dengan brace. Dalam paper ini, deskripsi tentang brace diberikan sebagai suatu perumuman dari radikal Jacobson dari suatu ring. Konstruksi brace dua sisi juga diberikan dalam artikel ini.
\end{abstract}

Kata Kunci: Grup abelian, brace, persamaan Yang-Baxter, radikal Jacobson.

\begin{abstract}
In the development of science, mathematics and physics are basic sciences that are used as a fundamental aspect for another branch of science. In the development of physics, we often found some notions which motivated some new inventions in Mathematics, especially in algebra. On the other hand, many problems in theoretical physics can be solved by using the algebraic approach. In this chance, one of the proof the relationship between physics and mathematics (especially in algebra) is given. In 1967, a fundamental equation in physics had been found by Nobel laureate C. $N$ Yang. In the same period, this fundamental equation was also claimed by R.J Baxter. Hence, this fundamental equation is called the YangBaxter equation. In fact, the Yang-Baxter equation has a significant impact on science, for example, in Knot Theory. However, the analytics solution of the Yang-Baxter equation has not been found until now. This condition motivates some researchers to find the solution to the Yang-Baxter equation via qualitative research or quantitative research. Some qualitative approach of the Yang-Baxter equation solution has been developed by using an approach type of algebraic structure, namely, brace. In this paper, the description of the brace will be given as a generalization of the Jacobson radical of rings. The construction of two-sided braces is also given in this paper.
\end{abstract}

Keywords: Abelian group, brace, Yang-Baxter equation, Jacobson radical. 


\section{Pendahuluan}

Persamaan Yang-Baxter pertama kali muncul dalam bidang fisika teoritis. Persamaan YangBaxter ini ditemukan oleh Fisikawan penerima hadiah Nobel C. N. Yang dalam paper [1]. Selain itu, persamaan Yang-Baxter juga ditemukan dalam [2] dan [3] karya R. J Baxter dengan bidang statistika mekanik. Persamaan Yang-Baxter ini merupakan salah satu persamaan fundamental dalam fisika matematis yang menjadi dasar dalam perkembangan Teori Knot dan perkembangan grup Braid [4]. Ilustrasi Teori Knot dan grup Braid ditunjukkan oleh gambar berikut ini.

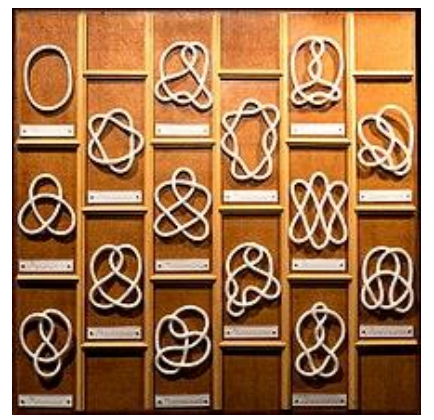

Gambar 1. Ilustrasi Teori Knot (Simpul) [5].

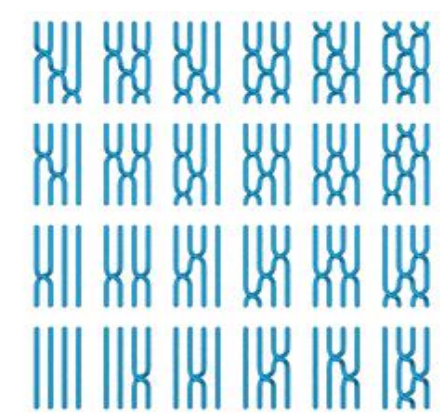

Gambar 2. Representasi Visual Grup Braid berorder 24 [6].

Contoh grup Braid berorder 24 sendiri adalah grup permutasi $S_{4}$ yang memiliki anggota $4 !=$ 4.3.2.1 = 24 dengan operasi komposisi. Selain itu, dampak adanya persamaan Yang-Baxter juga dapat ditemukan dalam bidang kuantum mekanik [4]. Hal ini memotivasi para peneliti untuk mencari solusi dari persamaan Yang-Baxter. Solusi yang diperoleh saat ini terbagi menjadi dua jenis, yaitu solusi dengan pendekatan kualitatif, yaitu dengan menggunakan aksioma-aksioma aljabar dan dengan pendekatan kuantitatif dengan menggunakan solusi numerik [7]. Akan tetapi secara umum, solusi analitiknya masih belum ditemukan hingga saat ini [4]. Beberapa solusi dapat ditemukan dalam [8] dan [9]. Selain itu, Agata Smoktunowicz dalam [10] dan [11] juga memberikan solusi alternatif dari sudut pandang teori himpunan. Selanjutnya, solusi dengan pendekatan teori himpunan juga diberikan oleh Castelli, et.al dalam papernya [12] dan Matsumoto \& Shimizu dalam [13]. Solusi yang diperumum diberikan oleh [14] dengan menggunakan struktur 
aljabar baru yang disebut dengan brace. Brace pertama kali dikenalkan pada tahun 2007 oleh Wolfgang Rump dalam papernya [15]. Adapun konsep dan sifat-sifat dasar brace akan dikaji lebih lanjut pada bagian berikutnya. Di lain pihak, solusi numerik dalam bentuk matriks diberikan oleh Smoktunowicz dalam papernya [7].

\section{Metode Penelitian}

Metode yang digunakan dalam penelitian ini adalah metode kualitatif dengan menggunakan hasil-hasil penelitian sebelumnya melalui proses literature study dan library research. Adapun langkah-langkah dalam penelitian ini adalah dijelaskan dalam beberapa tahapan berikut ini.

\subsection{Menelaah Konsep Brace}

Sebagai tahap awal dalam penelitian ini, pengetahuan tentang brace merupakan dasar untuk mengembangkan teori-teori baru dalam aljabar abstrak. Adapun langkah-langkah dalam tahapan awal ini adalah memahami definisi brace serta memberikan contoh-contoh brace dari hasil-hasil yang sudah ada.

\subsection{Menelaah Konsep Dalam Teori Radikal Yang Berkaitan Dengan brace}

Adapun topik dalam penelitian ini adalah Teori Radikal. Teori Radikal merupakan salah satu cabang dalam aljabar abstrak yang saat ini masih sangat luas pengembangannya. Hal ini ditunjukkan dengan adanya permasalahan terbuka atau open problem. Dalam kesempatan ini, dasar-dasar Teori Radikal yang dapat digunakan untuk melengkapi hasil yang berkaitan tentang brace adalah radikal Jacobson.

\subsection{Konstruksi Hasil}

Setelah menguasai konsep tentang brace dan radikal Jacobson, maka langkah berikutnya adalah memberikan syarat perlu dan syarat cukup agar suatu himpunan merupakan brace. Selanjutnya, akan diberikan hubungan brace dengan radikal yang lain seperti radikal prima $\boldsymbol{\beta}$, radikal Levitzki $\mathcal{L}$, dan radikal nil $\mathcal{N}$. Pada akhir bagian dalam hasil penelitian ini, diberikan konsep ring secara khusus yang merupakan brace. Adapun ring yang secara khusus digunakan dalam hasil penelitian ini merupakan ring himpunan semua bilangan rasional dengan pembilang (numerator) berupa bilangan genap dan penyebut (denumerator) berupa bilangan ganjil. Himpunan ini dinotasikan sebagai berikut

$$
W=\left\{\frac{2 x}{2 y+1} \mid \operatorname{gcd}(2 x, 2 y+1)=1, x, y \in \mathbb{Z}\right\} .
$$

Matematikawan yang pertama kali menemukan ring ini adalah Nathan Jacobson yang sekaligus pertama kali menemukan radikal Jacobson. Adapun hasil akhir dalam penelitian ini, 
ditunjukkan bahwa ring $\boldsymbol{W}=\left\{\frac{2 x}{2 y+1} \mid \operatorname{gcd}(2 x, 2 y+1)=1, x, y \in \mathbb{Z}\right\}$ yang ditemukan oleh Nathan Jacobson merupakan brace.

\section{Brace}

Untuk mempermudah proses penyelidikan diberikan definisi brace kiri, brace kanan, dan brace dua sisi di bawah ini yang ekuivalen dengan definisi brace oleh Rump [15].

Definisi 1 [11] Suatu himpunan tak kosong A disebut brace kiri jika operasi biner (+) dan (.) sedemikian hingga $(B,+)$ merupakan grup abelian dan $(B,$.$) merupakan grup yang belum tentu$ komutatif dan memenuhi sifat $a .(b+c)+a=a . b+a . c$ untuk setiap $a, b, c \in B$. Didefinisikan dengan cara yang sama, disebut brace kanan jika $(b+c) \cdot a+a=b \cdot a+c . a$. Himpunan $(B,+,$.$) disebut brace dua sisi jika merupakan brace kiri sekaligus brace kanan.$

Untuk memperjelas definisi di atas, diberikan teorema di bawah ini untuk menunjukkan eksistensi brace kiri.

Teorema 2 [16] Misalkan $A=\mathbb{Z} /(2 p)$ dengan $p$ adalah bilangan prima. Himpunan A membentuk brace kiri yang bukan merupakan brace kanan.

\section{Bukti.}

Didefinisikan produk atas $A, x_{1} \cdot x_{2}=x_{1}+(-1)^{x_{1}} x_{2}$. Kemudian dapat dengan mudah ditunjukkan bahwa $A$ merupakan brace kiri. Sebaliknya perhatkan bahwa $(1+1) \cdot 1=2.1+1=$ $2+(-1)^{2}+1=4$ dan $1.1+1.1=0+0=0$. Dengan demikian dapat disimpulkan bahwa himpunan $A$ merupakan brace kiri akan tetapi bukan brace kanan.

Contoh 1 [16] Diberikan grup abelian $A$ dan didefinisikan $a . a^{\prime}=a+a^{\prime}$ untuk setiap $a, a^{\prime} \in A$. Grup abelian $A$ dengan operasi biner (.) membentuk brace dua sisi. Contoh ini merupakan bentuk brace yang trivial.

Eksistensi brace dalam perkembangan ilmu aljabar abstrak khususnya teori ring sangatlah penting. Penelitian tentang brace dilanjutkan oleh para peneliti aljabar dengan mengkaji generalisasinya seperti yang ditunjukkan dalam paper [14], [17] dan [18]. Selain itu, hubungan braces dengan struktur grup juga diberikan oleh [19]. 


\section{$4 \quad$ Pengantar Teori Radikal Ring}

Dalam bagian ini akan diberikan beberapa definisi fundamental seperti ring prima, ring nil, ring nilpotent, dan ring quasi-beraturan sebagai landasan yang akan digunakan dalam menyelidiki sifat-sifat brace yang berkaitan dengan teori radikal ring.

Definisi 3 [20] Diketahui ring A. Suatu elemen $a \in A$ disebut elemen nilpotent jika terdapat bilangan bulat positif $n$ sehingga $a^{n}=0$. Ring $A$ disebut ring nil jika setiap elemen dari ring $A$ merupakan elemen nilpotent. Di lain pihak, ring A disebut ring nilpotent jika terdapat bilangan bulat positif $n$ sehingga $A^{n}=0$.

Definisi 4 [20] Suatu ideal $P$ dari ring A disebut ideal prima jika I,J ideal A dengan sifat IJ $\subseteq P$, maka berlaku $I \subseteq P$ atau $J \subseteq P$. Ring $A$ disebut ring prima jika $\{0\}$ merupakan ideal prima. Selanjutnya ring $A$ disebut ring quasi-beraturan jika dengan operasi biner (०) atas A yang didefinisikan oleh $a \circ b=a+b+a b$ untuk setiap $a, b \in A$ membentuk grup.

Kontribusi hasil penelitian dalam paper ini dalam perkembangan Ilmu Matematika khususnya Aljabar Abstrak yaitu memberikan konstruksi brace dua sisi dari sudut pandang Teori Radikal Ring. Sebelum diberikan konstruksi brace dua sisi, didefinisikan suatu operasi biner * atas himpunan tak kosong $B$ sebagai berikut

$$
a * b=a . b-a-b
$$

Berikut merupakan syarat perlu dan syarat cukup agar suatu himpunan merupakan brace dua sisi.

Teorema 5 [20] Himpunan tak kosong $(B,+,$.$) merupakan brace dua sisi jika dan hanya jika$ $(a+b) * c=a * c+b * c$ untuk setiap $a, b, c \in B$.

\section{Bukti.}

Jelas dalam [20].

Teorema 5 di atas merupakah salah satu alat yang digunakan untuk menghubungkan antara brace dan radikal Jacobson. Oleh sebab itu pada bagian ini akan diberikan konsep-konsep kelas radikal ring.

Definisi 6 [21] Suatu kelas ring $\gamma$ disebut sebagai kelas ring yang tertutup terhadap homomorfisma ring jika untuk setiap $A \in \gamma$, maka $A / I \in \gamma$ untuk setiap ideal I dari A. 
Untuk memperjelas eksistensi kelas yang tertutup terhadap homomorfisma perhatikan contoh-contoh berkut ini.

Contoh 2 [21] Perhatikan kelas ring $\mathcal{N}$ yang terdiri dari semua ring nil. Ingat kembali definisi ring nil. Suatu ring $A$ disebut ring nil jika untuk setiap $a \in A$ terdapat bilangan bulat positif $n$ sehingga $a^{n}=0$. Perhatikan bahwa setiap peta dari suatu homomorfisma ring dapat direpresentasi sebagai ring faktor $A / I$ dengan $I$ ideal $A$. Oleh sebab itu, dapat diambil sebarang $I$ yang merupakan ideal $A$. Selanjutnya diambil sebarang $\bar{a} \in A / I$, maka $\bar{a}$ dapat direpresentasikan sebagai $\bar{a}=a+I$ dengan $a \in A$. Karena $A$ merupakan ring nil, maka terdapat bilangan bulat positif $n$ sehingga $a^{n}=$ 0 . Selanjutnya, $\bar{a}^{n}=(a+I)^{n}=a^{n}+I=0+I=\overline{0}$. Oleh sebab itu, dapat disimpulkan bahwa setiap elemen $\bar{a} \in A$ merupakan elemen nilpotent. Dengan kata lain, dapat disimpulkan bahwa ring faktor $A / I$ merupakan ring nil.

Untuk memperkuat konsep, setelah diberikan contoh kelas ring yang bersifat tertutup terhadap homomorfisma, berikut ini merupakan contoh kelas ring yang tidak tertutup terhadap homomorfisma.

Contoh 3 [21] Perhatikan kelas ring $\pi$ yang terdiri dari semua ring prima. Pada contoh berikut akan ditunjukkan bahwa kelas semua ring prima $\pi$ merupakan kelas ring yang tidak tertutup terhadap homomorfisma dengan counter example. Perhatikan ring $W=\left\{\frac{2 x}{2 y+1} \mid \operatorname{gcd}(2 x, 2 y+\right.$ $1)=1, x, y \in \mathbb{Z}\}$. Jelas bahwa ring $W$ merupakan ring yang elemen-elemennya adalah himpunan bilangan-bilangan dengan numerator genap dan denumetaror ganjil dan ring $W$ merupakan ring prima dengan ideal-idealnya membentuk kondisi rantai menurun (descending chain condition) dapat direpresentasikan sebagai $\left(2^{m}\right)$ dengan $m \in \mathbb{N}$. Akan tetapi ring faktornya bukan merupakan ring prima karena setiap ring faktornya dapat direpesentasikan sebagai $\frac{\left(2^{m}\right)}{\left(2^{k}\right)}$ dengan $m \geq k$ sedemikian sehingga $\left(\frac{\left(2^{m}\right)}{\left(2^{k}\right)}\right)^{2}=\{\overline{0}\}$. Oleh sebab itu, $\frac{\left(2^{m}\right)}{\left(2^{k}\right)}$ merupakan ring nilpotent yang mengakibatkan $\frac{\left(2^{m}\right)}{\left(2^{k}\right)}$ bukan merupakan ring prima. Dengan demikian $\frac{\left(2^{m}\right)}{\left(2^{k}\right)} \notin \pi$. Jadi $\pi$ tidak tertutup terhadap homomorfisma. 
Definisi 7 [21] Suatu kelas ring $\gamma$ disebut sebagai kelas ring yang memiliki sifat induktif jika $I_{1} \subseteq$ $\cdots \subseteq I_{\lambda} \subseteq \cdots$ merupakan rantai naik ideal-ideal dari suatu ring $A$ dan jika setiap $I_{\lambda} \in \gamma$, maka $U$ $I_{\lambda} \in \gamma$.

Untuk memperjelas struktur kelas ring yang memiliki sifat induktif dan tidak, perhatikan dua contoh kelas ring sebagai berikut.

Contoh 4 Dapat ditunjukkan bahwa kelas ring $\mathcal{N}$ yang terdiri dari semua ring nil merupakan kelas ring yang memiliki sifat induktif [21].

Contoh 5 Kelas ring $\mathcal{N}_{0}$ yang terdiri dari semua ring nilpotent tidak memiliki sifat induktif. Penjelasan dan pembuktikan secara lengkap telah ada dalam [21].

Definisi 8 [21] Suatu kelas ring $\gamma$ disebut tertutup terhadap perluasan jika untuk setiap ring A sehingga terdapat I yang merupakan ideal A dengan sifat I dan ring faktor A/I berada dalam kelas ring $\gamma$, maka A juga merupakan anggota $\gamma$.

Definisi 9 [21] Suatu kelas ring $\gamma$ disebut kelas radikal ring jika $\gamma$ tertutup terhadap homomorfisma, memiliki sifat induktif dan tertutup terhadap perluasan.

Salah satu contoh kelas radikal adalah kelas semua ring nil $\mathcal{N}$ yang ditunjukkan oleh [22] pada Lemma 3. Berdasarkan konstruksinya, ada dua jenis konstruksi, yaitu kontruksi radikal atas dan konstruksi radikal bawah. Dua kontruksi kelas radikal ini dapat ditemukan dalam [22] dan [21]. Dari kontruksi tersebut, terdapat radikal atas yang dibangun oleh kelas khusus antara lain radikal prima $\beta$, radikal Levitzki $\mathcal{L}$, dan radikal Jacobson $\mathcal{J}$. Berdasarkan sifatnya, kelas radikalkelas radikal ini merupakan anggota dari lattice semua kelas radikal supernilpotent. Dalam lattice tersebut, radikal prima $\beta$ merupakan elemen terkecil. Adapun bagian lattice tersebut diilustrasikan oleh gambar di bawah ini.

$$
\beta-\mathcal{L}-\mathcal{N}-\mathcal{J}
$$

Gambar 3. Ilustrasi Hubungan Antara $\beta, \mathcal{L}, \mathcal{N}$ dan $\mathcal{J}$. 
Kelas radikal prima $\beta$ termuat dengan tegas dalam kelas radikal Levizki $\mathcal{L}$, kelas radikal levitzki $\mathcal{L}$ termuat secara tegas dalam kelas radikal nil $\mathcal{N}$ dan kelas radikal nil termuat secara tegas dalam kelas radikal Jacobson $\mathcal{J}$. Hal dijelaskan karena adanya contoh berikut ini.

Contoh 6 [21] Misalkan $K$ merupakan lapangan berhingga dan $K\langle x, y\rangle$ merupakan polinomial aljabar atas $K$ dalam $x$ dan $y$ yang tidak berlaku sifat komutatif. Perhatikan bahwa himpunan $K\langle x, y\rangle$ merupakan himpunan yang terhitung atau countable maka himpunan ini dapat dinotasikan dengan $R$ yang merupakan polinomial dengan konstanta nol. Dengan mencacah elemenelemennya, maka elemen $R$ dapat dinotasikan dengan $\left\{u_{1}, u_{2}, \ldots\right\}$. Selanjutnya, misalkan $I$ merupakan himpunan tak kosong yang merupakan ideal $R$ yang dibangung oleh semua $s_{i j}$, dengan rincian elemen $S_{i j}$ dapat diperoleh dari [21]. Lebih lanjut, dalam [21] ditunjukkan bahwa ring faktor $R / I$ merupakan elemen dari kelas radikal nil $\mathcal{N}$ tetapi $R / I$ bukan anggota kelas radikal Levizki $\mathcal{L}$. Oleh sebab itu $\mathcal{N} \neq \mathcal{L}$. Kemudian perhatikan bahwa setiap elemen nilpotent dari suatu ring merupakan elemen quasi-beraturan kiri seperti yang dijelaskan dalam Proposisi 4.4.4 [21]. Akibatnya, setiap ring nil merupakan ring quasi-beraturan. Oleh sebab itu, setiap ring nil termuat dalam kelas radikal Jacobson $\mathcal{J}$. Sebaliknya perhatikan ring $\mathcal{W}$ yang didefinisikan oleh

$$
\mathcal{W}=\left\{\frac{2 x}{2 y+1} \mid \operatorname{gcd}(x, y)=1 ; x, y \in \mathbb{Z}\right\}
$$

Perhatikan bahwa ring $\mathcal{W}$ merupakan salah satu anggota dalam kelas radikal Jacobson seperti yang dijelaskan dalam [21]. Akan tetapi, perhatikan bahwa ring $\mathcal{W}$ bukanlah ring nil. Dengan demikian $\mathcal{N} \neq \mathcal{J}$.

Berdasarkan sifat lattice dari semua kelas radikal supernilpotent dan Contoh 10 yang diberikan di atas dapat disimpulkan bahwa $\beta \subset \mathcal{L} \subset \mathcal{N} \subset \mathcal{J}$. Akan tetapi dapat ditemukan ringring tertentu sehingga berlaku $\beta(A)=\mathcal{L}(A)=\mathcal{N}(A)=\mathcal{J}(A)$. Dengan masing-masing $\beta(A), \mathcal{L}(A), \mathcal{N}(A)$ dan $\mathcal{J}(A)$ adalah $\beta(A)=\sum\{I$ ideal ring $A \mid I \in \beta\}, \mathcal{L}(A)=\sum\{I$ ideal ring $A \mid I \in$ $\mathcal{L}\}, \mathcal{N}(A)=\sum\{I$ ideal ring $A \mid I \in \mathcal{N}\}$, dan $\mathcal{J}(A)=\sum\{I$ ideal ring $A \mid I \in \mathcal{J}\}$. Oleh sebab itu, untuk sebarang ring $A$ berlaku sifat berikut ini,

$$
\beta(A) \subseteq \mathcal{L}(A) \subseteq \mathcal{N}(A) \subseteq \mathcal{J}(A)
$$




\section{$5 \quad$ Hasil dan Pembahasan}

Pada teorema-teorema berikutnya akan dibahas tentang kaitan antara kelas radikal Jacobson $\mathcal{J}$ dengan brace yang telah diperkenalkan pada bagian sebelumnya. Sebagai pendahuluan diberikan teorema sebagai berikut yang merupakan alat hubung antara brace dan radikal Jacobson.

Teorema 10 [1] Misalkan B merupakan himpunan tak kosong. Himpunan B yang dilengkapi dengan dua operasi biner yaitu (+) dan (.) merupakan brace dua sisi jika dan hanya jika $(B,+, *)$ merupakan ring Jacobson, dengan kata lain, $B \in \mathcal{J}$ dan operasi biner $(*)$ merupakan operasi yang didefinisikan pada Persamaan 1.

\section{Bukti.}

Diketahui himpunan tak kosong $B$ yang dilengkapi dengan dua operasi biner yaitu $(+)$ dan (.) merupakan brace dua sisi. Akan ditunjukkan bahwa $(B,+, *)$ merupakan ring Jacobson yang artinya berdasarkan definisi pembentukkan kelas ring Jacobson harus ditunjukkan bahwa $(B, \circ)$ membentuk grup dengan ( ${ }^{\circ}$ ) merupakan operasi biner atas $B$ yang didefinisikan oleh $a \circ b=a+$ $b+a * b$ untuk setiap $a, b \in B$. Selanjutnya diambil sebarang $a, b \in B$, maka berdasarkan definisi operasi biner ( $(\circ)$ diperoleh $a \circ b=a+b+a * b$, akibatnya $a * b=a \circ b-a-b$. Selanjutnya perhatian Persamaan 1, maka operasi biner ( ${ }^{\text {) }}$ sama dengan operasi (.) yang telah didefnisikan pada $B$ dengan memandang $(B,+,$.$) sebagai brace. Oleh sebab itu (B, \circ)$ membentuk grup, sehingga dapat disimpulkan bahwa $(B,+, *)$ merupakan ring Jacobson.

Sebaliknya diketahui $(B,+, *)$ merupakan ring Jacobson, akan ditunjukkan bahwa $(B,+,$. membentuk brace dua sisi. Karena $(B,+, *)$ merupakan ring Jacobson, maka jelas bahwa $(B,$. membentuk grup. Selanjutnya diambil sebarang $a, b, c \in B$, sehingga diperoleh $(a+b) * c=a * c+b * c$ karena $(B,+, *)$ merupakan ring sehingga berlaku sifat distributif. Dengan demikian berdasarkan Teorema 5 dapat disimpulkan bahwa $(B,+,$.$) membentuk brace$ dua sisi.

Sebagai akibat dari teorema di atas dan sifat yang dimiliki oleh kelas radikal prima $\beta$, kelas radikal Levitzki $\mathcal{L}$, kelas radikal nil $\mathcal{N}$, dan kelas radikal Jacobson $\mathcal{J}$ dalam lattice semua kelas radikal supernilpotent, diperoleh akibat sebagai berikut.

Teorema 11 Diketahui ring A dan himpunan-himpunan berikut $\beta(A), \mathcal{L}(A), \mathcal{N}(A), \mathcal{J}(A)$ berturutturut merupakan radikal prima, Levitzki radikal, radikal nil, dan radikal Jacobson dari ring A. 
Dapat ditunjukkan bahwa $\beta(A), \mathcal{L}(A), \mathcal{N}(A)$, dan $\mathcal{J}(A)$ masing-masing merupakan brace dua sisi.

\section{Bukti.}

Berdasarkan sifat lattice dari semua radikal supernilpotent diperoleh $\beta \subset \mathcal{L} \subset \mathcal{N} \subset \mathcal{J}$ [2]. Oleh sebab itu untuk sebarang ring $A$ berlaku $\beta(A) \subseteq \mathcal{L}(A) \subseteq \mathcal{N}(A) \subseteq \mathcal{J}(A)$. Dengan masing-masing $\beta(A), \mathcal{L}(A), \mathcal{N}(A), \mathcal{J}(A)$ merupakan ideal-ideal terbesar dari ring $A$ yang masing-masing termuat dalam kelas radikal $\beta, \mathcal{L}, \mathcal{N}, \mathcal{J}$. Oleh sebab itu $\beta(A), \mathcal{L}(A), \mathcal{N}(A), \mathcal{J}(A) \in \mathcal{J}$. Dengan demikian $(A), \mathcal{L}(A), \mathcal{N}(A), \mathcal{J}(A)$ masing-masing merupakan ring Jacobson. Jadi berdasarkan Teorema 10, dapat disimpulkan bahwa $(A), \mathcal{L}(A), \mathcal{N}(A)$, dan $\mathcal{J}(A)$ masing-masing membentuk brace dua sisi.

Pada teorema berikut akan dijelaskan eksistensi contoh nyata dari suatu brace dua sisi dengan menggunakan Teorema 10.

Teorema 12 Didefinisikan himpunan $W=\left\{\frac{2 x}{2 y+1} \mid \operatorname{gcd}(2 x, 2 y+1)=1, x, y \in \mathbb{Z}\right\}$. Struktur $(W,+,$.$) merupakan brace dua sisi, dengan a . b=a+b+(a \times b)$ untuk setiap $a, b \in W$.

\section{Bukti.}

Berdasarkan Teorema 10, untuk menunjukkan bahwa himpunan

$$
W=\left\{\frac{2 x}{2 y+1} \mid \operatorname{gcd}(2 x, 2 y+1)=1, x, y \in \mathbb{Z}\right\},
$$

merupakan brace dua sisi cukup ditunjukkan bahwa $W$ merupakan ring Jacobson. Dengan kata lain akan ditunjukkan bahwa $(W, \circ)$ membentuk grup dengan $a \circ b=a+b+(a \times b)$ untuk setiap $a, b \in W$ [2]. Untuk membuktikan bahwa $(W, \circ)$ merupakan grup, akan dijabarkan dalam empat tahap.

1. Diambil sebarang $a_{1}, a_{2} \in W$, maka $a_{1}$ dan $a_{2}$ dapat direpresentasikan sebagai

$$
a_{1}=\frac{2 x_{1}}{2 y_{1}+1}, a_{2}=\frac{2 x_{2}}{2 y_{2}+1}
$$

dengan $\operatorname{gcd}\left(2 x_{1}, 2 y_{1}+1\right)=\operatorname{gcd}\left(2 x_{2}, 2 y_{2}+1\right)=1$. Selanjutnya perhatikan perkalian berikut ini

$$
\begin{aligned}
a_{1} \circ a_{2} & =\frac{2 x_{1}}{2 y_{1}+1}+\frac{2 x_{2}}{2 y_{2}+1}+\left(\frac{2 x_{1}}{2 y_{1}+1} \times \frac{2 x_{2}}{2 y_{2}+1}\right) \\
& =\frac{2 x_{1}}{2 y_{1}+1}+\frac{2 x_{2}}{2 y_{2}+1}+\frac{4 x_{1} x_{2}}{\left(2 y_{1}+1\right)\left(2 y_{2}+1\right)}
\end{aligned}
$$




$$
\begin{aligned}
& =\frac{2 x_{1}\left(2 y_{2}+1\right)+2 x_{2}\left(2 y_{1}+1\right)+4 x_{1} x_{2}}{\left(2 y_{1}+1\right)\left(2 y_{2}+1\right)} \\
& =\frac{4 x_{1} y_{2}+2 x_{1}+4 x_{2} y_{1}+2 x_{2}+4 x_{1} x_{2}}{4 y_{1} y_{2}+2 y_{1}+2 y_{2}+1} \\
a_{1} \circ a_{2} & =\frac{2\left(2 x_{1} y_{2}+x_{1}+2 x_{2} y_{1}+x_{2}+2 x_{1} x_{2}\right)}{2\left(2 y_{1} y_{2}+y_{1}+y_{2}\right)+1}
\end{aligned}
$$

Untuk

$$
\operatorname{gcd}\left(2\left(2 x_{1} y_{2}+x_{1}+2 x_{2} y_{1}+x_{2}+2 x_{1} x_{2}\right), 2\left(2 y_{1} y_{2}+y_{1}+y_{2}\right)+1\right)=1
$$

Jelas mengakibatkan $a_{1} \circ a_{2} \in W$.

Untuk

$$
\operatorname{gcd}\left(2\left(2 x_{1} y_{2}+x_{1}+2 x_{2} y_{1}+x_{2}+2 x_{1} x_{2}\right), 2\left(2 y_{1} y_{2}+y_{1}+y_{2}\right)+1\right) \neq 1
$$

Misalkan

$$
\operatorname{gcd}\left(2\left(2 x_{1} y_{2}+x_{1}+2 x_{2} y_{1}+x_{2}+2 x_{1} x_{2}\right), 2\left(2 y_{1} y_{2}+y_{1}+y_{2}\right)+1\right)=d
$$

Untuk suatu bilangan bulat positif $d \neq 1$. Dengan kata lain bilangan rasional

$$
\frac{2\left(2 x_{1} y_{2}+x_{1}+2 x_{2} y_{1}+x_{2}+2 x_{1} x_{2}\right)}{2\left(2 y_{1} y_{2}+y_{1}+y_{2}\right)+1}
$$

bukan dalam primitif atau pecahan yang paling sederhana. Lebih lanjut diperoleh

$$
\frac{2\left(2 x_{1} y_{2}+x_{1}+2 x_{2} y_{1}+x_{2}+2 x_{1} x_{2}\right)}{2\left(2 y_{1} y_{2}+y_{1}+y_{2}\right)+1}=\frac{\frac{2\left(2 x_{1} y_{2}+x_{1}+2 x_{2} y_{1}+x_{2}+2 x_{1} x_{2}\right)}{d}}{\frac{2\left(2 y_{1} y_{2}+y_{1}+y_{2}\right)+1}{d}} \text {. }
$$

Dengan memperhatikan bahwa

$$
\operatorname{gcd}\left(2\left(2 x_{1} y_{2}+x_{1}+2 x_{2} y_{1}+x_{2}+2 x_{1} x_{2}\right), 2\left(2 y_{1} y_{2}+y_{1}+y_{2}\right)+1\right)=d,
$$

maka

$$
\frac{2\left(2 x_{1} y_{2}+x_{1}+2 x_{2} y_{1}+x_{2}+2 x_{1} x_{2}\right)}{d}
$$

dan

$$
\frac{2\left(2 y_{1} y_{2}+y_{1}+y_{2}\right)+1}{d}
$$

Masing-masing merupakan bilangan bulat. Lebih lanjut dengan menggunakan sifat dasar dalam great common divisor yang telah kita pelajari dalam teori bilangan, dipenuhi sifat

$$
\operatorname{gcd}\left(\frac{2\left(2 x_{1} y_{2}+x_{1}+2 x_{2} y_{1}+x_{2}+2 x_{1} x_{2}\right)}{d}, \frac{2\left(2 y_{1} y_{2}+y_{1}+y_{2}\right)+1}{d}\right)=1
$$

Yang menjamin bahwa bilangan rasional

$$
\frac{2\left(2 x_{1} y_{2}+x_{1}+2 x_{2} y_{1}+x_{2}+2 x_{1} x_{2}\right)}{2\left(2 y_{1} y_{2}+y_{1}+y_{2}\right)+1}
$$


dapat disederhanakan dalam bentuk pecahan paling sederhana katakan

$$
\frac{2\left(2 x_{1} y_{2}+x_{1}+2 x_{2} y_{1}+x_{2}+2 x_{1} x_{2}\right)}{2\left(2 y_{1} y_{2}+y_{1}+y_{2}\right)+1}=\frac{m}{n}
$$

dengan sifat $m$ bilangan genap dan $n$ bilangan ganjil sedemikian sehingga $\operatorname{gcd}(m, n)=1$. Lebih lanjut karena $m$ bilangan genap dan $n$ bilangan ganjil, maka $m$ dapat direpresentasikan sebagai $m=2 m_{1}$ untuk suatu $m_{1} \in \mathbb{Z}$ dan $n=2 n_{1}+1$ untuk suatu $n_{1} \in \mathbb{Z}$. Hal ini juga mengakibatkan $a_{1} \circ a_{2} \in W$. Dengan demikian dapat disimpulkan bahwa operasi biner ( $\left.{ }^{\circ}\right)$ atas $W$ bersifat tertutup. Untuk memperjelas ilustrasi tahapan 1 perhatikan bahwa bilangan rasional

$$
\frac{2}{3}, \frac{4}{3} \in W
$$

dengan sifat $\operatorname{gcd}(2,3)=\operatorname{gcd}(4,3)=1$. Lebih lanjut perhatikan

$$
\frac{2}{3} \circ \frac{4}{3}=\frac{2}{3}+\frac{4}{3}+\left(\frac{2}{3} \times \frac{4}{3}\right)=\frac{6}{3}+\frac{8}{9}=\frac{26}{9} \in W
$$

Dilain pihak andaikata ditemui hasil operasi o yang menghasilkan bilangan rasional $\frac{6}{9}$. Meskipun $\operatorname{gcd}(6,9)=3 \neq 1$, bilangan rasional $\frac{6}{9}$ juga merupakan anggota $W$ dengan memperhatikan bahwa

$$
\frac{6}{9}=\frac{2}{3}
$$

Dengan sifat $\operatorname{gcd}(2,3)=1$.

2. Diambil sebarang $a_{1}, a_{2}, a_{3} \in W$, sehingga diperoleh

$$
\begin{aligned}
\left(a_{1} \circ a_{2}\right) \circ a_{3} & =\left(a_{1}+a_{2}+a_{1} a_{2}\right) \circ a_{3} \\
& =a_{1}+a_{2}+a_{3}+a_{1} a_{2}+a_{1} a_{3}+a_{2} a_{3}+a_{1} a_{2} a_{3} \\
& =a_{1} \circ\left(a_{2}+a_{3}+a_{2} a_{3}\right) \\
\left(a_{1} \circ a_{2}\right) \circ a_{3} & =a_{1} \circ\left(a_{2} \circ a_{3}\right) .
\end{aligned}
$$

Dengan demikian dapat disimpulkan bahwa operasi biner ( ${ }^{\circ}$ ) atas $W$ bersifat asosiatif.

3. Perhatikan bahwa terdapat $0 \in W$ dengan sifat $a \circ 0=a+0+a .0=a$ untuk setiap $\in$ $a \in W$. Jadi $W$ memuat elemen identitas.

4. Diambil sebarang $a_{1} \in W$, akan ditentukan $a_{2} \in W$ dengan sifat $a_{1} \circ a_{2}=0$. Perhatikan $a_{1} \in W$, maka

$$
a_{1}=\frac{2 x_{1}}{2 y_{1}+1}
$$

dengan $\operatorname{gcd}\left(2 x_{1}, 2 y_{1}+1\right)=1$ dan $x_{1}, y_{1} \in \mathbb{Z}$. Selanjutnya,

$$
a_{1}+a_{2}+a_{1} a_{2}=0 \text {, }
$$




$$
\begin{gathered}
\frac{2 x_{1}}{2 y_{1}+1}+a_{2}+\left(\frac{2 x_{1}}{2 y_{1}+1}\right) a_{2}=0, \\
a_{2}+\left(\frac{2 x_{1}}{2 y_{1}+1}\right) a_{2}=-\frac{2 x_{1}}{2 y_{1}+1}, \\
\left(\frac{2 y_{1}+1}{2 y_{1}+1}\right) a_{2}+\left(\frac{2 x_{1}}{2 y_{1}+1}\right) a_{2}=-\frac{2 x_{1}}{2 y_{1}+1}, \\
\left(\frac{\left(2 y_{1}+1\right) 2 x_{1}}{2 y_{1}+1}\right) a_{2}=-\frac{2 x_{1}}{2 y_{1}+1}, \\
a_{2}=-\frac{2 x_{1}}{2 y_{1}+1}\left(\frac{2 y_{1}+1}{\left(2 y_{1}+1\right) 2 x_{1}}\right), \\
a_{2}=-\frac{2\left(\frac{2 x_{1} y_{1}+x_{1}}{\left(2 y_{1}+1\right) 2 x_{1}}\right)}{2 y_{1}+1} \in W .
\end{gathered}
$$

Berdasarkan empat langkah penjabaran di atas, dapat disimpulkan bahwa $(W, \circ)$ merupakan grup. Oleh sebab itu, $W$ merupakan ring Jacobson. Kemudian berdasarkan Teorema 10 dan Teorema 11 , ring $W$ merupakan brace dua sisi.

\section{Simpulan}

Berdasarkan hasil peneliti-peneliti sebelumnya, brace merupakan salah satu struktur dalam aljabar abstrak yang digunakan sebagai alat untuk menentukan solusi dari persamaan Yang-Baxter. Oleh sebab itu, mengkaji sifat-sifat brace sangat penting bagi perkembangan Aljabar Abstrak khsususnya Teori Ring. Berdasarkan sifatnya, brace dibagi menjadi tiga yaitu brace kiri, brace kanan, dan brace dua sisi. Hasil dalam penelitian ini adalah memberikan kontruksi brace dua sisi dari sudut pandang teori radikal ring, yaitu dengan menggunakan konsep ring Jacobson dan radikal Jacobson.

\section{Ucapan Terima Kasih}

Penulis mengucapkan terimakasih kepada reviewer serta semua pihak yang telah memberikan masukan dan saran dalam menyempurnakan paper ini. Penulis juga mengucapkan terimakasih kepada LPPM Universitas Ahmad Dahlan atas kontrak penelitian nomor PD120/SP3/LPPM-UAD/2020

\section{Daftar Pustaka}

[1] C. N. Yang, "Some Exact Results For The Many-Body Problem In One Dimension with Repulsive," Phys. Rev. Lett., vol. 19, no. 23, pp. 1312-1315, 1967. 
[2] R. Baxter, "Partition function of the Eight-Vertex lattice model," Ann. Phys. (N. Y)., vol. 70, no. 1, pp. 193-228, Mar. 1972.

[3] R. Baxter, Exactly Solved Models in Statistical Mechanics. London, UK: Academic Press, 1982.

[4] F. Nichita, "Introduction to the Yang-Baxter Equation with Open Problems," axioms, vol. 1, no. 1, pp. 33-37, Apr. 2012.

[5] Wikipedia, “en.wikipedia.org," Wikimedia Foundation, Inc, 2019. [Online]. Available: https://en.wikipedia.org/wiki/Knot_theory. [Accessed: 26-Feb-2020].

[6] Wikipedia, “en.wikipedia.org,” Wikimedia Foundation, Inc, 2020. [Online]. Available: https://en.wikipedia.org/wiki/Braid_group. [Accessed: 26-Feb-2020].

[7] A. Smoktunowicz and A. Smoktunowicz, "Set-theoretic solutions of the Yang-Baxter equation and new classes of R-matrices," Linear Algebra Appl., vol. 546, pp. 86-114, Jun. 2018.

[8] T. Gateva-Ivanova, "A combinatorial approach to the set-theoretic solutions of the YangBaxter equation,” J. Math. Phys., vol. 45, no. 10, pp. 3828-3858, Oct. 2004.

[9] R. Larry A, Lambe dan David E, Introduction to the quantum Yang-Baxter equation and quantum groups: An algebraic approach. In Mathematics and Its Applications 423.

Dordrecht, The Netherlands: Kluwer Academic Publishers, 1997.

[10] A. Smoktunowicz, "On Engel groups, nilpotent groups, rings, braces and the Yang-Baxter equation,” Trans. Am. Math. Soc., vol. 370, no. 9, pp. 6535-6564, Mar. 2018.

[11] A. Smoktunowicz, "A note on set-theoretic solutions of the Yang-Baxter equation," J. Algebr., vol. 500, pp. 3-18, Apr. 2018.

[12] M. Castelli, F. Catino, and G. Pinto, "About a question of Gateva-Ivanova and Cameron on square-free set-theoretic solutions of the Yang-Baxter equation," Commun. Algebr., vol. 48, no. 6, pp. 1-13, Jun. 2020.

[13] D. K. Matsumoto and K. Shimizu, "Quiver-theoretical approach to dynamical YangBaxter maps,” J. Algebr., vol. 507, pp. 47-80, Aug. 2018.

[14] F. Cedó, A. Smoktunowicz, and L. Vendramin, "Skew left braces of nilpotent type," Proc. London Math. Soc., vol. 118, no. 6, pp. 1367-1392, Jun. 2019.

[15] W. Rump, "Braces, radical rings, and the quantum Yang-Baxter equation," J. Algebr., vol. 307, no. 1, pp. 153-170, Jan. 2007.

[16] D. B. Pérez, "Study Of The Algebraic Structure Of Left Braces And The Yang-Baxter Equation," Universitat Autonoma de Barelona, 2016.

[17] E. Acri and M. Bonatto, "Skew braces of size pq," Commun. Algebr., vol. 48, no. 5, pp. 1- 
20, May 2020.

[18] L. Guarnieri and L. Vendramin, "Skew braces and the Yang-Baxter equation," Math. Comput., vol. 86, no. 307, pp. 2519-2534, Nov. 2017.

[19] D. B. Pérez, "Counterexample to a conjecture about braces," J. Algebr., vol. 453, pp. 160176, May 2016.

[20] F. Cedó, T. Gateva-Ivanova, and A. Smoktunowicz, "Braces and symmetric groups with special conditions," J. Pure Appl. Algebr., vol. 222, no. 12, pp. 3877-3890, Dec. 2018.

[21] B. J. Gardner and R. Wiegandt, Radical Theory of Rings. New York: Marcel Dekker, Inc, 2004.

[22] P. W. Prasetyo, S. Wahyuni, I. E. Wijayanti, and H. France-Jackson, "Dari Radikal Ring Ke Radikal Modul (From Radical Of Rings To Radical Of Modules),” Pros. Semin. Nas. Mat. Univ. Jember, 2014. 